\title{
Rare Earth Element Determination in Olivine by Laser Ablation-Quadrupole-ICP-MS: An Analytical Strategy and Applications
}

\author{
Clare V. Stead (1)*, Emma L. Tomlinson (1), Balz S. Kamber (1), Michael G. Babechuk (2) and \\ Cora A. McKenna (1)
}

(1) Department of Geology, Trinity College Dublin, Dublin 2, Ireland

(2) Department of Geosciences, University of Tübingen, 72074, Tübingen, Germany

* Corresponding author. e-mail: steadcv@tcd.ie

Olivine offers huge, largely untapped, potential for improving our understanding of magmatic and metasomatic processes. In particular, a wealth of information is contained in rare earth element (REE) mass fractions, which are well studied in other minerals. However, REE data for olivine are scarce, reflecting the difficulty associated with determining mass fractions in the low $\mathrm{ng} \mathrm{g}^{-1}$ range and with controlling the effects of LREE contamination. We report an analytical procedure for measuring REEs in olivine using laser ablation quadrupole-ICP-MS that achieved limits of determination (LOD) at sub-ng $g^{-1}$ levels and biases of $\sim 5-10 \%$. Empirical partition coefficients ( $D$ values) calculated using the new olivine compositions agree with experimental values, indicating that the measured REEs are structurally bound in the olivine crystal lattice, rather than residing in micro-inclusions. We conducted an initial survey of REE contents of olivine from mantle, metamorphic, magmatic and meteorite samples. REE mass fractions vary from 0.1 to double-digit $\mathrm{ng} \mathrm{g}^{-1}$ levels. Heavy REEs vary from low mass fractions in meteoritic samples, through variably enriched peridotitic olivine to high mass fractions in magmatic olivines, with fayalitic olivines showing the highest levels. The variable enrichment in HREEs demonstrates that olivine REE patterns have petrological utility.

Keywords: laser ablation, quadrupole-ICP-MS, olivine, rare earth elements, partitioning, in situ analysis.

Received 11 Mar 16 - Accepted 07 Nov 16

Olivine is the most abundant mineral in upper mantle peridotite. It is also present in stony and stony-iron meteorites and occurs as inclusions in diamonds (Sobolev et al. 2008). Despite its low affinity for the rare earth elements (REEs), olivine's high modal abundance makes it an important contributor to heavy REE (HREE) fractionation (Sun and Liang 2013) in magmatic systems. Olivine is one of the first minerals to form in crystallising mafic magmas on both sides of the thermal divide (Bowen 1915). Without understanding the role of olivine, our comprehension of magmatic and metasomatic processes will remain incomplete. The isovalent REEs are particularly useful in petrogenetic studies, as they display characteristic partitioning behaviour linked to their ionic radii (Nagasawa 1966, Bau 1996). Many experimental studies have determined how the REEs partition into rock-forming minerals confirming the systematic behaviour resulting from the small changes in ionic radii from Lu $(0.977 \AA)$ to La (1.16 ^) (in VIII co-ordination) (Shannon 1976). For many silicate minerals, the HREEs display stronger compatibility than both the middle and light REEs (MREEs and LREEs) (Onuma et al. 1968, Van Orman et al. 2001), although in detail this is dependent of the size of the site into which the REEs are partitioning. To date, there have been relatively few studies of minor and trace element characteristics in olivine (Lee et al. 2007, Spandler and O'Neill 2009, De Hoog et al. 2010, Foley et al. 2013) and even fewer have determined the REE (Eggins et al. 1998b, Zanetti et al. 2004, Lee et al. 2007). The scarcity of empirical REE data for olivine reflects, firstly, the analytical difficulty associated with determining mass fractions in the low $\mathrm{ng} \mathrm{g}^{-1}$ range, and, secondly, the obstacles of minimising the effects of LREE contamination on grain boundaries and from inclusions (Lee et al. 2007). Experimental work (McDade et al. 2003, Zanetti et al. 2004) and lattice strain modelling (Lee et al. 2007) indicate that olivine has a preference for HREE over the lighter rare earth elements, demonstrated, for example, by the olivine/clinopyroxene 


\section{GEOSTANDARDS and \\ GEOANALYTICAL \\ RESEARCH}

partition coefficients of the order of $10^{-2}$ for $\mathrm{Yb}$ and $10^{-5}$ for $\mathrm{La}$ (McDade et al. 2003, Zanetti et al. 2004).

In this contribution, we describe a new analytical approach using LA-Q-ICP-MS as a macrosampling tool (100-200 $\mu \mathrm{m}$ scale) to determine REE in olivine. This approach offers a further step towards tapping into the wealth of information locked into olivine and could help unravel the often complex and multi-stage metasomatic histories in mantle rocks and improve our knowledge of mantle melting and magma generation. We present REE data for a selection of olivine materials across a range of lithologies, assessing REE variability in olivine. We use these data to investigate REE partitioning in olivine and discuss our findings in relation to previous experimental and theoretical work.

\section{Sample description}

Olivine grains from eighteen samples were hand-picked and analysed in this study. The samples were chosen to represent a range of lithologies, localities and forsterite (Fo) content. Samples are divided into four groups: mantle, magmatic, metamorphic and meteorite. Sample localities and characteristics are described in Table 1. Mantle olivine grains were selected from dunites, harzburgites and Iherzolites, thus covering a wide range of apparent melt depletion. Grain size varied from 1 to $5 \mathrm{~mm}$ and Fo ranged from 85\% to $91 \%$ with $\mathrm{NiO}$ ranging from ca. 0.2 to $0.6 \mathrm{~g} / 100 \mathrm{~g}$. Samples originate from many localities including xenoliths from both shallow, spinel facies lithospheric mantle and from garnet-bearing lithospheric mantle.

Magmatic samples range from tholeiitic to basanitic and include both intrusive and extrusive (porphyritic) representatives. Grain size varied from 1 to $7 \mathrm{~mm}$ and Fo ranged from $30 \%$ to $90 \%$, encompassing forsteritic and fayalitic olivine compositions. Average $\mathrm{NiO}$ content was lower than for mantle olivine, at ca. $0.2 \mathrm{~g} / 100 \mathrm{~g}$

Two meteorite samples were analysed. Both of these are pallasitic, that is stony-iron meteorites. The Springwater meteorite olivine grains were fragments $<0.5 \mathrm{~mm}$ in diameter donated by the Smithsonian Institute, while the Jepara meteorite olivine grains ranged in size from 1 to $4 \mathrm{~mm}$. The Fo contents were $82 \%$ and $87 \%$, respectively.

Table 1.

Sample characteristics

\begin{tabular}{|c|c|c|c|c|}
\hline Name & Location & Source rock & Source & Previous publications \\
\hline \multicolumn{5}{|l|}{ Magmatic } \\
\hline P16029* & Margi, Cyprus & Volcanic - picrite & TCD collection & \\
\hline P16180 & Waimarino, New Zealand & Mafic - basalt & TCD collection & \\
\hline $\mathrm{P} 16034$ & Etna, Sicily & Mafic - basalt & TCD collection & \\
\hline Sk22 & Skaergaard Layered Intrusion (UZb) & Hortonolite ferrodiorite & TCD collection & \\
\hline Sk24 & Skaergaard Layered Intrusion (UZa) & Hortonolite-ferrodiorite & TCD collection & \\
\hline Sk31 & Skaergaard Layered Intrusion (LZb) & Olivine-hypersthene gabbro & TCD collection & \\
\hline $\mathrm{P} 1655$ & Coverack, Cornwall & Gabbroic - troctolite & TCD collection & \\
\hline \multicolumn{5}{|l|}{ Mantle } \\
\hline P16028 & Dun, New Zealand & Ultramafic - dunite & TCD collection & \\
\hline P16030* & Meerfelder Maar & Ultramafic - spinel-Iherzolite & TCD collection & \\
\hline P5372 & Newlands Mine, SA & Ultramafic - garnet harzburgite & TCD collection & \\
\hline P16032 & Vulture, Italy & Ultramafic - spinel lherzolite & TCD collection & \\
\hline P16031 & Puerto del Carmen, Lanzarote & Ultramafic - harzburgite & lan Meighan & \\
\hline P16033 & Hawaii & Ultramafic - dunite & TCD collection & $\begin{array}{l}\text { Published as sample ER63-33 (Roedder } \\
\text { 1965, Murck et al. 1978) }\end{array}$ \\
\hline P16035 & & Ultramafic - spinel Iherzolite & TCD collection & \\
\hline P32003 & Tallante, Spain & Ultramafic - spinel lherzolite & TCD collection & \\
\hline P5508 & Mont Briançon & Ultramafic - spinel Iherzolite & TCD collection & \\
\hline KH 96-21 & Kilbourne Hole & Ultramafic - spinel harzburgite & Jason Harvey & Harvey et al. (2012) \\
\hline NMNH & San Carlos, Arizona & Ultramafic - Iherzolite & Smithsonian Institute & \\
\hline \multicolumn{5}{|c|}{$111312-44 * *$} \\
\hline \multicolumn{5}{|l|}{ Metamorphic } \\
\hline P15759 & Loch Duich, Scotland & Forsterite marble & TCD collection & \\
\hline \multicolumn{5}{|l|}{ Meteorite } \\
\hline P16027 & Indonesia & Pallasite meteorite & Commercial & \\
\hline USNM & Springwater & Pallasite meteorite & Smithsonian Institute & \\
\hline $2566 * *$ & & & & \\
\hline
\end{tabular}

*Denotes in-house olivine reference material, **denotes Smithsonian reference material. 


\section{GEOSTANDARDS and GEOANALYTICAL}

A single metamorphic sample, a forsterite marble, was analysed. Average grain size was $2 \mathrm{~mm}$. During handpicking of this sample, discoloured and cloudy grains were found. These were avoided to minimise possible alteration effects. The Fo content was ca. $95 \%$.

Individual olivine crystals from each sample were handpicked to optical purity, selected to be free from external contamination and inclusions, and wherever possible, broken internal fragments were chosen. Crystals were subsequently mounted in epoxy resin.

\section{Analytical methods}

\section{Major element EDS}

Major elements were determined by SEM-EDS (scanning electron microscope-energy-dispersive spectroscopy) at the Centre for Microscopy and Analysis (CMA) at Trinity College Dublin (TCD). This was carried out using a Tescan Mira XMU instrument, equipped with an 80- $\mathrm{mm}^{2}$ silicon drift energydispersive detector, and the Oxford Inca X-ray microanalysis software. Accelerating voltage was $20 \mathrm{kV}$, with a beam current of $1 \mathrm{nA}$. The instrument was calibrated using a suite of appropriate mineral reference materials from the Smithsonian Institute (Jarosewich et al. 1980). Biases for MgO, $\mathrm{SiO}_{2}$ and $\mathrm{FeO}$ for the reference materials $\mathrm{NMNH} 111312$ $44(n=14)$ and USNM $2566(n=10)$ were $<2.7 \%$ relative to reported reference values (Jarosewich et al. 1980).

\section{Laser ablation-quadrupole-ICP-MS}

Rare earth element mass fractions were determined in situ by LA-Q-ICP-MS using an Analyte Excite excimer laser ablation system (Teledyne Photon Machines, Bozeman, MT, USA) at Trinity College Dublin between February and September of 2015. The laser ablation system was equipped with a 193-nm ATLex 300 ArF excimer laser and a HelEx II two-volume ablation cell and attached to an iCAP-Qc quadrupole ICP-MS (Thermo Fisher Scientific, Bremen, Germany).

In the earlier measurement sessions, the collision cell was used in kinetic energy discrimination (KED) mode (employing grade 6.0 $\mathrm{N} \mathrm{He}$ as collision gas) for two reasons: firstly, to increase mid- to high-mass sensitivities through collisional focussing and secondly to suppress the signal in the low mass range and avoid exposing the detector to excessive signals from higher abundance elements such as $\mathrm{Si}$. As the study progressed, the collision gas inlet developed a small air leak that led to increased oxide rates and suspected $\mathrm{N}$ O-metal molecular interferences, affecting Sc and Ga.

Subsequent experiments were run in standard mode without the use of the collision cell to avoid interferences on Sc and Ga. The REE data produced in both KED and standard modes were scrutinised and found to be in complete agreement, showing that these elements were not affected by molecular interferences in the earlier experiments run using KED mode. Typical sensitivities measured for a tuning line (85$\mu \mathrm{m}$ spot, $10 \mathrm{~Hz}$ repetition rate, $40 \mu \mathrm{m} \mathrm{s}^{-1}$ scan speed) on NIST SRM 612 were as follows: ${ }^{7} \mathrm{Li} 53000$ cps, ${ }^{140} \mathrm{Ce}$ 300000 cps, ${ }^{172}$ Yb 120000 cps, ${ }^{232}$ Th 460000 cps, ${ }^{230} \mathrm{U}$ 495000 cps.

For olivine analysis, a very large spot size, high frequency and untypically long dwell times were used, as outlined in Table 2, to maximise the REE signal. Ablation sites were chosen away from external boundaries to avoid fractures that may have introduced contamination. A spot size of $160 \mu \mathrm{m}$ and a laser repetition rate of $30 \mathrm{~Hz}$ were used, which resulted in pit depths of $165 \mu \mathrm{m}$. This arrangement allowed for $>3$ replicates per grain in large grains. The volume of ablated material resulted in ca. $500 \mu \mathrm{g}$ of olivine being carried to the plasma via an in-house-developed signal-smoothing device.

Under these particular experimental conditions, oxide production could be higher than in normal laser ablation analysis due to the high ablation rate required to produce a detectable signal. The latter leads to lower plasma temperature and associated increased oxide rates. The $\mathrm{ThO} / \mathrm{Th}^{+}$ ratio was monitored for experiments run in both standard and KED modes and found to be consistently below $0.2 \%$ in standard mode and below $2 \%$ in KED mode. No correction for oxide interference was employed, but possible analytical artefacts due to unaccounted oxide interference were tested by quantifying the data with two reference materials with very different relative REE abundance: BHVO-2G (Basalt, Hawaiian Volcanic Observatory, a natural reference material with Oddo-Harkins effect abundances) and NIST SRM 612 (an artificial equal atom reference material). The resulting REE patterns of samples were statistically not resolvable despite the very different relative production rates of LREE and MREE oxides from these reference materials, showing that oxide formation had a negligible effect on final measured values. The agreement between REE mass fractions for those samples run in both standard and KED modes provides additional support for uncorrected oxide interferences. Finally, a SiC semiconductor wafer was analysed to investigate the effect of high-purity aerosol particles on measured backgrounds. The wafer background was found to be within uncertainty of the 
RESEARCH

Table 2.

Laser ablation quadrupole-ICP-MS operating parameters

\begin{tabular}{|c|c|c|c|c|}
\hline \multicolumn{5}{|l|}{ Laser parameters } \\
\hline Fluence & $4.87 \mathrm{~J} \mathrm{~cm}^{-2}$ & & & \\
\hline Repetition rate & $30 \mathrm{~Hz}$ & & & \\
\hline Shot count & 4200 & & & \\
\hline Laser spot size & $160 \mathrm{~mm}$ & & & \\
\hline Average pit depth & $165 \mathrm{~mm}$ & & & \\
\hline He cell gas flow & $0.651 \mathrm{~min}^{-1}$ & & & \\
\hline $\mathrm{N}_{2}$ trace gas flow & $6 \mathrm{ml} \mathrm{min}-1$ & & & \\
\hline Sampling strategy & Spot & & & \\
\hline Background measurement & $60 \mathrm{~s}$ & & & \\
\hline \multicolumn{5}{|l|}{ ICP-MS parameters } \\
\hline RF power & $1550 \mathrm{~W}$ & & & \\
\hline Mode & $\begin{array}{l}\text { Collision Cell (CCTS) and } \\
\text { Standard (STDS) }\end{array}$ & & & \\
\hline Nebuliser gas flow & $0.7 \mid \mathrm{min}^{-1}$ & & & \\
\hline Collision cell gas flow $(\mathrm{He})$ in & $5.3 \mathrm{ml} \mathrm{min}-1$ & & & \\
\hline \multicolumn{5}{|c|}{ KED mode } \\
\hline & Element & Set $A(s)$ & Set B (s) & Set C (s) \\
\hline Dwell time (s) configurations & ${ }^{27} \mathrm{Al}$ & 0.002 & 0.002 & 0.002 \\
\hline \multirow[t]{15}{*}{ and analytes } & ${ }^{29} \mathrm{Si} *$ & 0.002 & 0.002 & 0.002 \\
\hline & ${ }^{45} \mathrm{Sc}$ & & 0.001 & 0.001 \\
\hline & ${ }^{71} \mathrm{Ga}$ & & 0.08 & \\
\hline & ${ }^{89} Y$ & 0.02 & 0.02 & \\
\hline & ${ }^{139} \mathrm{La}$ & 0.35 & 0.4 & \\
\hline & ${ }^{140} \mathrm{Ce}$ & 0.25 & 0.15 & 0.15 \\
\hline & ${ }^{141} \operatorname{Pr}$ & & 2.15 & \\
\hline & ${ }^{146} \mathrm{Nd}$ & 2.5 & 2.5 & \\
\hline & ${ }^{147} \mathrm{Sm}$ & & & 2.5 \\
\hline & ${ }^{153} \mathrm{Eu}$ & & & 2.5 \\
\hline & ${ }^{160} \mathrm{Gd}$ & 2.5 & 2 & \\
\hline & ${ }^{163} \mathrm{Dy}$ & & & 2.5 \\
\hline & ${ }^{166} \mathrm{Er}$ & 1 & 0.35 & \\
\hline & ${ }^{172} \mathrm{Yb}$ & 0.35 & 0.35 & 0.35 \\
\hline & Total & 6.974 & 8.005 & 8.005 \\
\hline
\end{tabular}

*Denotes the internal standard element.

gas background for all REEs (see Table S4), showing that no scrubbing of elements from the sample cell or aerosol transfer path occurred.

The untypically long dwell times used here, up to $2.5 \mathrm{~s}$ for MREE, resulted in a long sweep time of $\sim 8 \mathrm{~s}$, with the high shot count (4200) allowing for twenty sweeps per analyte. Most analyses were performed with the 'set $A$ ' element dwell time configuration given in Table 2. This is a short analyte set, covering only a selection of REE across the mass range. Due to the long dwell time required and the maximum sweep time of the iCAP-Q, we needed to run two analyses to obtain a more complete REE data set. For this full REE characterisation, we used configuration sets ' $\mathrm{B}$ ' and ' $\mathrm{C}$ ' in sequence, each targeting different analytes as outlined in Table 2, with overlaps at Ce and Yb to ensure comparability.

Data reduction was carried out using lolite software v2.5 (Paton et al. 2011) and Si, known from major element determination, was used as the internal standard element using the trace element internal standard data reduction scheme (IS DRS). A gas blank subtraction was carried out using this DRS, with typical background count rates provided in Table S4. The resulting Si signal on the Q-ICP-MS was very large and in order to preserve detector lifetime, a very short (2 ms) dwell time was employed. USGS reference glass $\mathrm{BHVO}-2 \mathrm{G}$ was used as the calibration reference material, while NIST SRM 616 and 612 and MPI-DING GOR132-G were used as quality control reference materials (Max-PlanckInstitut für Chemie - Dingwell) (Jochum et al. 2006, 201 1). Two samples, one magmatic and one mantle, were chosen as in-house reference materials for this work (Table 1). These samples were selected due to their large exposed surface areas ( $>4 \mathrm{~mm}$ diameter) in the mounts, relatively high REE mass fractions, and high degree of homogeneity $(n=8-10)$. Homogeneity of samples was previously determined using EDS transects across the mineral surface ( $n=8$ spot analyses per transect) and was also demonstrated in replicate trace element determinations. Typical relative standard deviation (\% RSD) for $\mathrm{Mg}$ and $\mathrm{Si}$ were $<2 \%$, while for Fe this was $<3 \%$. 


\section{GEOSTANDARDS and GEOANALYTICAL}

\section{Solution Q-ICP-MS}

Solution Q-ICP-MS analysis was carried out on the inhouse olivine reference material P16029 using the same iCap-Q at Trinity College Dublin in November 2015 for comparison with the LA-Q-ICP-MS data. Three individual olivine crystals were broken from the hand specimen and aliquots from these were hand-picked to select the clearest possible internal fragments. A range of aliquot sizes was picked, where the smallest were expected to yield the purest olivine signature. Nevertheless, the mass of all aliquots could not be accurately determined on the balance and olivine grains were transferred to Teflon beakers without weighing.

In view of the widely acknowledged (e.g., Eggins et al. 1998a, b, Lee et al. 2007) issue of alteration and concomitant contamination with incompatible trace elements, the aliquots were divided into two fractions, one to be cleaned by leaching and the other to be left unleached. Leaching was carried out in three stages using a method adapted from Eggins et al. (1998a, b) whereby grains were subjected to a 30-min leach in $\sim 2 \mathrm{~mol}^{-1} \mathrm{HCl}$, followed by a 15-min leach in $\sim 1 \mathrm{~mol} \mathrm{I}^{-1} \mathrm{HF}$, and a final overnight soak in boiling Milli-Q water. Unleached samples were rinsed in Milli-Q water only. All samples were then digested in a 4:1 $\mathrm{HF}-\mathrm{HNO}_{3}$ mixture. Sequential addition and removal of acid was necessary to fully digest the unmilled (higher mass) grain fragments, which proved to negatively impact the procedural blank and associated correction on all samples. Once digested, the solution and fluorides were evaporated, and the residue converted to nitrates using two stages of concentrated $\mathrm{HNO}_{3}$ addition. All acids used were purified using in-house sub-boiling triple distillation.

One way to measure the very low REE contents in olivine is to coprecipitate and concentrate them after digestion. This helps to avoid matrix issues and boosts sensitivity for measurement (e.g., Qi et al. 2005). However, in order to overcome inherent blank issues, a reasonably large sample mass is required. Because of the very small aliquots hand-picked in this study, the coprecipitation step was not deemed appropriate. Instead, final solutions of relatively low dilution factors were prepared directly for analysis by dissolving the nitrate residue in $2 \mathrm{ml}$ of $\sim 0.3 \mathrm{~mol} \mathrm{l}^{-1} \mathrm{HNO}_{3}$ spiked with a mixed internal standard of ${ }^{6} \mathrm{Li}, \mathrm{Rh}, \mathrm{Re}, \mathrm{Bi}^{235} \mathrm{U}$.

A sample volume of $1 \mathrm{ml}$ was introduced into the Q-ICPMS using a microFast system coupled to an ESI SC-2 DX autosampler at a rate of $140 \mu \mathrm{min}^{-1}$ (allowing for ca. 7 min of data collection). Typical sensitivities (cps per $\mathrm{ng} \mathrm{g}^{-1}$ ) measured after tuning the Q-ICP-MS were as follows: ${ }^{59} \mathrm{Co}$ 132000 cps, ${ }^{140} \mathrm{Ce} 320000$ cps, ${ }^{209} \mathrm{Bi} 370000$ cps, ${ }^{238} \mathrm{U}$ $500000 \mathrm{cps}$. Experiment set-up followed the approach of Eggins et al. (1997) with the modifications as outlined in later publications (e.g., Babechuk et al. 2010). Sample unknowns were preceded with blanks, multiple analyses of the calibration material (USGS rock reference material W-2) and quality control reference materials (USGS rock reference material BIR-1) all spiked with the same internal standard element mixture. Interleaved between these samples was a monitor solution (an additional rock reference material) to correct for external drift. Beyond the REE $+\mathrm{Y}$, a small suite of other elements (Al, Ca, Mn, Fe, Mg, Sc, Cr, Co, Ni, Rb, Zr and Th) was also determined. Instrument intensities were corrected offline for internal and external drift, procedural blank and isobaric interferences, and calibrated using the preferred values of W-2 reported elsewhere (Kamber 2009).

The intensities of several of the high field-strength elements ( $Z r$, Th and Sc) showed excessive (up to 50\%) drift in some of the samples. The drift of all the other analytes was small $(<5 \%)$ and correlated exactly with the internal standard intensities. The difficulty in digesting the samples also manifested as residual solids (colloids) that remained and did not fully dissolve into $\sim 0.3 \mathrm{~mol} \mathrm{l}^{-1}$ $\mathrm{HNO}_{3}$. Drifting elemental data for those samples are not reported. Nearly all REE intensities were above the background equivalent concentration (BEC) calculated from multiple measurements of the blank internal standard mixture. However, as expected, the sample signal intensities for the REEs were low and progressively approached the levels of the procedural blank from the HREEs to LREEs. Accordingly, data for La to $\mathrm{Nd}$ were indeterminable above the blank. For the remaining REEs, only the blank-corrected solution concentrations that exceeded the value of the procedural blanks by a factor of 2 were considered reliable. This is demonstrated in online supporting information Table S1 and Figure S1, where the latter shows the $\mathrm{Cl}$-chondrite-normalised REE patterns of the BEC, procedural blanks and screened sample concentrations as described above. These REE data are used for comparison with those obtained by the LA-ICP-MS method. Rubidium, determined as a proxy for melt addition or metasomatism, was only detectable in one sample. The laboratory is continuing to refine the technique for single-crystal shard analysis by S-Q-ICP-MS.

The determination of $\mathrm{Fe}$ and $\mathrm{Mg}$ was used to scale the measured $\mathrm{FeO}+\mathrm{MgO} \mathrm{g} / 100 \mathrm{~g}$ to a sum of $59 \mathrm{~g} / 100 \mathrm{~g}$ based on SEM-EDS data that returned an average of $59.3 \pm 0.3$. For unleached samples, the factor by which the abundances were scaled is an indirect measure of the 
measurement dilution factor, which ranged from ca. 11000 to 38000 and corresponds to back-calculated olivine aliquot masses ranging from 0.05 to $0.18 \mathrm{mg}$. For leached samples, where an indeterminate amount of mass was lost, the scaling factor cannot provide a dilution factor. The scaled abundance data for leached and unleached samples are presented in Table S1.

\section{Results and discussion}

\section{Fractionation during LA-Q-ICP-MS analysis}

Fractionation can lead to inaccurate measured values in data if there are differences between analyte behaviour of samples and the calibration reference materials. It is especially important to monitor fractionation in view of the long dwell times used in this study. Many factors contribute towards fractionation at all stages of analysis, such as during aerosol transport and during ionisation in the plasma. At the laser ablation stage, the pit depth-diameter ratio has been identified as a key parameter in causing fractionation (Eggins et al. 1998a), with aspect ratios > 1 being unfavourable. Here, we limited the overall analysis time to maintain an aspect ratio of $\sim 1$.

Fractionation was monitored by calculation of the fractionation index relative to the internal standard ${ }^{29} \mathrm{Si}$ $\left(\mathrm{Fl}_{29}\right)$ (Fryer et al. 1995). The fractionation index measures the relative change between analyte signal and the internal standard $\left({ }^{29} \mathrm{Si}\right)$ over the duration of the analysis and was calculated as follows:

$$
\mathrm{FI}_{29}=\frac{\left(\mathrm{I}_{\mathrm{i}} / \mathrm{I}_{\mathrm{S}}\right) T_{0-64}}{\left(\mathrm{I}_{\mathrm{i}} / \mathrm{I}_{\mathrm{S}}\right) T_{65-130}}
$$

where $l_{i}$ is the mean intensity of the analyte mass and $I_{I S}$ is the mean intensity of ${ }^{29} \mathrm{Si}$ the internal standard element, for the two halves of data acquisition (total ablation time of $130 \mathrm{~s}$ per spot) where $\mathrm{T}$ is time in seconds. Where $\mathrm{Fl}_{29}$ deviates from 1, fractionation has occurred. Figure 1 shows $\mathrm{Fl}_{29}$ for the in-house olivine (P16029, P16030), soda-lime glass (NIST SRM 612, NIST SRM 616) and basalt glass (BHVO-2G, KL2-G, GOR132-G) reference materials. Typically, $\mathrm{Fl}_{29}$ clusters between 0.9 and 1.1 , indicating that no systematic or significant fractionation took place, and additionally there was no difference in fractionation between the glass and olivine matrices. In view of the aim of the study - to determine measured values at very low mass fractions with moderate precision - uncertainty introduced by fractionation was not significant during ablation, transport or detection, despite the high mass of sample material removed using this analytical set-up.

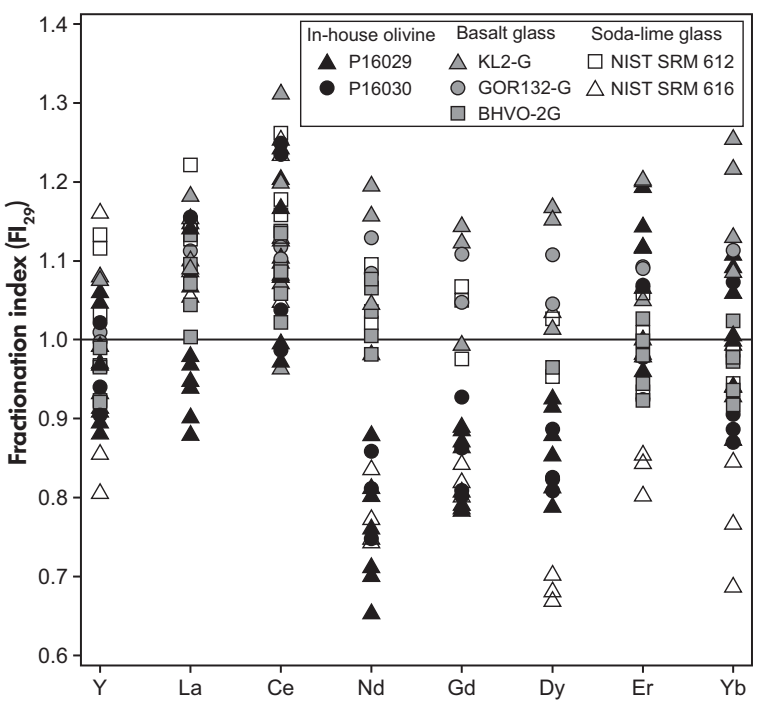

Figure 1. Variation in fractionation index (see text for definition) for glass and in-house olivine reference materials for a typical experimental run (April 2015).

\section{Data quality and comparison}

Limits of determination: We preferred the more conservative LOD to limits of detection, that is using six times the standard deviation $(s)$ of the background (measured as a gas blank) rather than the standard $3 s$, to ensure quantitative determinations. The LODs achieved using the LA-Q-ICP-MS technique were sub-ng $\mathrm{g}^{-1}$, typically 0.2 $0.4 \mathrm{ng} \mathrm{g}^{-1}$. The determined mass fractions of REEs in the samples in this study were consistently above LOD, typically at least ten times greater, with very few values falling below the limit. The two elements found most likely to fall below LOD were Pr and $\mathrm{Sm}$, even though their dwell times are at or close to the maximum allowable duration (2.5 s).

Trueness: Data trueness was assessed by calculation of relative bias (\%bias) of reference materials. The \%bias was determined for three reference materials: soda-lime glasses (NIST SRM 612, NIST SRM 616) (Jochum et al. 2011) and the basalt glass (GOR132-G) (Jochum et al. 2006) reference materials and is shown in Figure 2. A table of average measured values is provided in Table S2. The bias was typically 5-10\% for both the NIST SRM and the MPI-DING reference material glasses; however, there is a discrepancy for Ce values recorded for GOR132-G, averaging ca. 10\% lower than the reference value. The raw $\mathrm{Ce}$ signals for all experiments involving GOR132-G were examined and it was determined that this offset was not due to a switch between analogue (BHVO-2G) and pulse count (GOR132$G)$ modes, as the offset remained even in runs where both 


\section{GEOSTANDARDS and GEOANALYTICAL \\ RESEARCH}

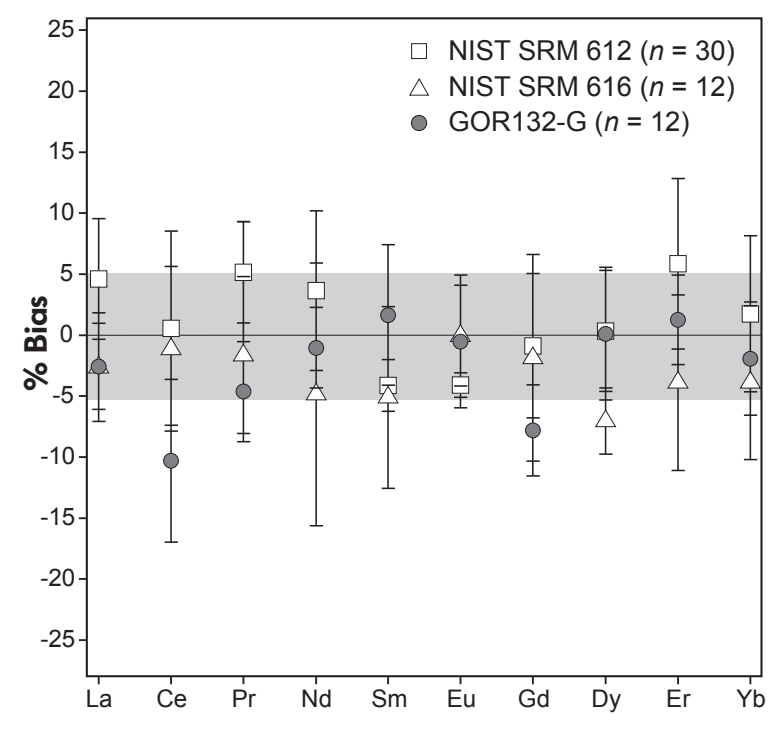

Figure 2. \%Bias (see text for definition) for three reference materials that were used as quality monitors for all experiments (February-September 2015), plotted in order of atomic mass. Range bars represent $1 \mathrm{~s}$. For ease of comparison, an area has been shaded to highlight the data that is within the $\pm 5 \%$ bias bracket.

signals were recorded in pulse count mode. Moreover, the Cl-normalised REE pattern for our average GOR132-G values determined here is smooth and shows no negative Ce anomaly. In addition, lower than preferred Ce values have previously been reported in the literature for this reference material (e.g., Gibson et al. 2013).

Regardless, the NIST SRM 616 measured values most closely resemble the levels in natural olivine grains and for this reference material we are able to achieve biases of $\pm 10 \%$ (typically) similar to the results for our in-house olivine reference materials, even at single-digit $\mathrm{ng} \mathrm{g}^{-1}$ mass fractions.

Precision: To a first order, the measurement repeatability is a function of counting statistics, predicting that large signals can be measured with much better precision than tiny signals such as those obtained for REEs in olivine. In our data sets, there is the expected trend of increasing precision (expressed as RSD of Si-normalised analyte signals) with an increasing signal but only in the signal range of $10^{\circ}$ to $10^{4}$ cps (Figure 3a). For signals $>10^{4} \mathrm{cps}$, the expected further improvement in measurement repeatability was not found. By contrast, in the few experiments where Al was also measured, Al-normalised signal measurement repeatability were lower and improved to $1-3 \%$ for signals of ca. $10^{6} \mathrm{cps}$ (Figure 3a). This discrepancy is explained with the irregularity of the $\mathrm{Si}$ signals in our experiments. At the chosen experimental conditions, the short dwell time for Si resulted in more irregular signals than those of comparably sized analyte signals (see Figure 3b for an example). Thus, for high mass fraction samples, the irregular $\mathrm{Si}$ signal degraded the quality of the measurement repeatability for high mass fraction analytes, and our method should not be used to analyse materials with higher REE mass fractions such as garnet or clinopyroxene.

Figure 3c shows the intermediate measurement precision, $1 \mathrm{~s}$, defined over the period February-September 2015 of REE measured values determined from repeat analyses of olivine $(n=7,10)$, basalt $(n=6,12)$ and soda-lime $(n=12,30)$ glass reference materials. When plotted against average analyte count rate, there is a general negative correlation across all matrix types. For very small signals, the measurement reproducibility approaches or is even lower than the measurement repeatability, which is a common observation for Q-ICP-MS data, even in solution mode (see e.g., Ulrich et al. 2010). For reference material analytes that yield larger signals (i.e., $>10^{4}$ (ps), the expected better intermediate precision was not observed, similar to the measurement repeatability (Figure 3a). Therefore, for large signals, our method yields unfavourably large errors. However, in view of the analytical targets with expected REE mass fractions of a few $n g \mathrm{~g}^{-1}$, the measurement reproducibility is $<10 \%$ (Figure 3c).

Figure 3d shows variation in \% RSD with observed REE mass fractions for two in-house olivine reference materials. This illustrates that to maintain an RSD of $<10 \%$, the mass fraction should be above $10 \mathrm{ng} \mathrm{g}^{-1}$. From Table 3, we know that the HREEs for both mantle and magmatic olivine grains are present at mass fractions $>10 \mathrm{ng} \mathrm{g}^{-1}$, and thus, the method should be able to achieve a \% RSD value of better than 10\%. The LREEs are consistently lower in measured value and are therefore subject to higher \% RSD values. Count rates, and thus measurement repeatability, for the LREEs could be improved by using an even larger laser spot size.

Solution Q-ICP-MS data and comparison with LA-QICP-MS data: Comparing the mass fractions in the leached and unleached aliquots of sample P16029, very good agreement was found for elements highly compatible in olivine: Co (146 $\pm 2 \mu \mathrm{g} \mathrm{g}^{-1}$ leached and $147 \pm 3 \mu \mathrm{g} \mathrm{g}^{-1}$ unleached), $\mathrm{Ni} \quad\left(2100 \pm 36 \mathrm{\mu g} \mathrm{g}^{-1}\right.$ leached and $2093 \pm 103 \mu \mathrm{g} \mathrm{g}^{-1} \quad$ unleached) and $\mathrm{Mn} \quad(0.150 \pm$ $0.002 \mathrm{~g} / 100 \mathrm{~g}$ leached and $0.153 \pm 0.005 \mathrm{~g} / 100 \mathrm{~g}$ unleached). Chromium also produced agreement between the two populations within uncertainty $\left(484 \pm 69 \mu \mathrm{g} \mathrm{g}^{-1}\right.$ leached and $417 \pm 55 \mu \mathrm{g} \mathrm{g}^{-1}$ unleached), with one 

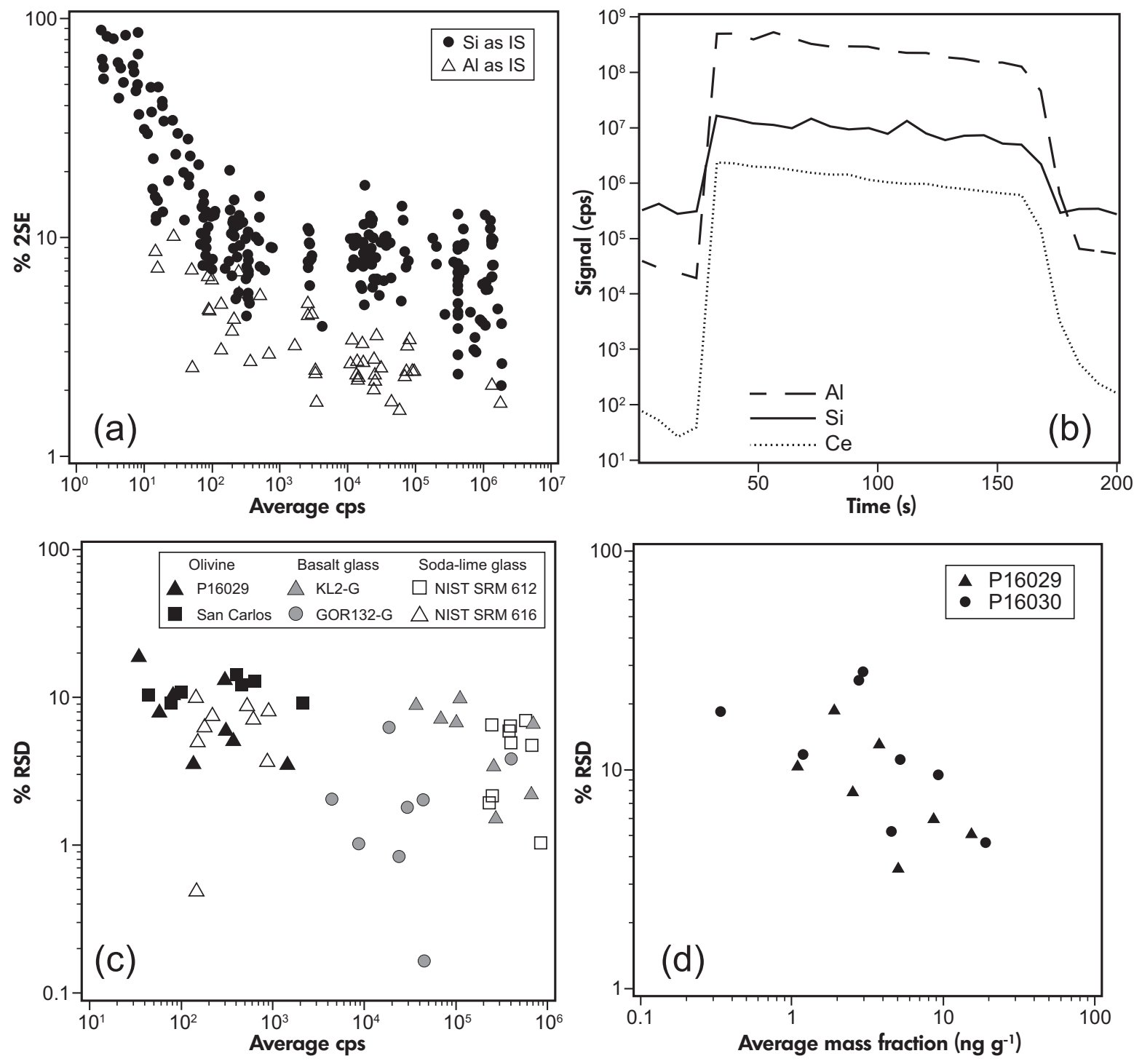

Figure 3. (a) Measurement repeatability (\% 2 standard error) plotted against average background-corrected signal (cps) for representative analytical runs, using $\mathrm{Si}$ and $\mathrm{Al}$ as internal standard elements for calibration, between February and September 2015. Relative standard deviation (\% RSD) was calculated for NIST SRM and MPI-DING reference materials and an in-house olivine reference material (P16029) as follows:

$\%$ RSD $=100 \times\left(\frac{\text { standard deviation } \text { of counts }]}{\text { average }[\text { of counts }]}\right)$ (b) Typical signals (cps) for Al, Si and Ce shown for a representative ablation of BHVO-2G. (c) RSD of determined mass fractions against average count rate of replicate analyses of NIST SRM and MPI-DING reference materials and two olivine samples from analytical runs between February and September 2015. (d) RSD against average mass fraction of individual REEs in $\mathbf{n g ~}^{-1}$ for a picritic olivine (sample P16029) and a spinel lherzolite (sample P16030) from analytical runs between February and September 2015.

exception (CS47, with Cr $586 \mu \mathrm{g} \mathrm{g}^{-1}$ ). These Ni-Co-Crvalues are within the range of values reported for other picritic olivine (e.g., Krishnamurthy et al. 2000, Zhang et al. 2008) and is in agreement with the measurement of $\mathrm{Ni}\left(2020 \pm 470 \mu \mathrm{g} \mathrm{g}^{-1}\right)$ determined via semiquantitative SEM-EDS as outlined above (see section Major element EDS). Collectively, these observations confirm that the $\mathrm{MgO}+\mathrm{FeO} \mathrm{g} / 100 \mathrm{~g}$ scaling procedure produced reliable final abundances. Further, the quality of correspondence in $\mathrm{Co}-\mathrm{Ni}-\mathrm{Cr}$ demonstrates that metasomatism, if present, did not significantly affect these elements in the olivine. The low Al and undetectable Rb in all samples but one (see below) can also be considered 


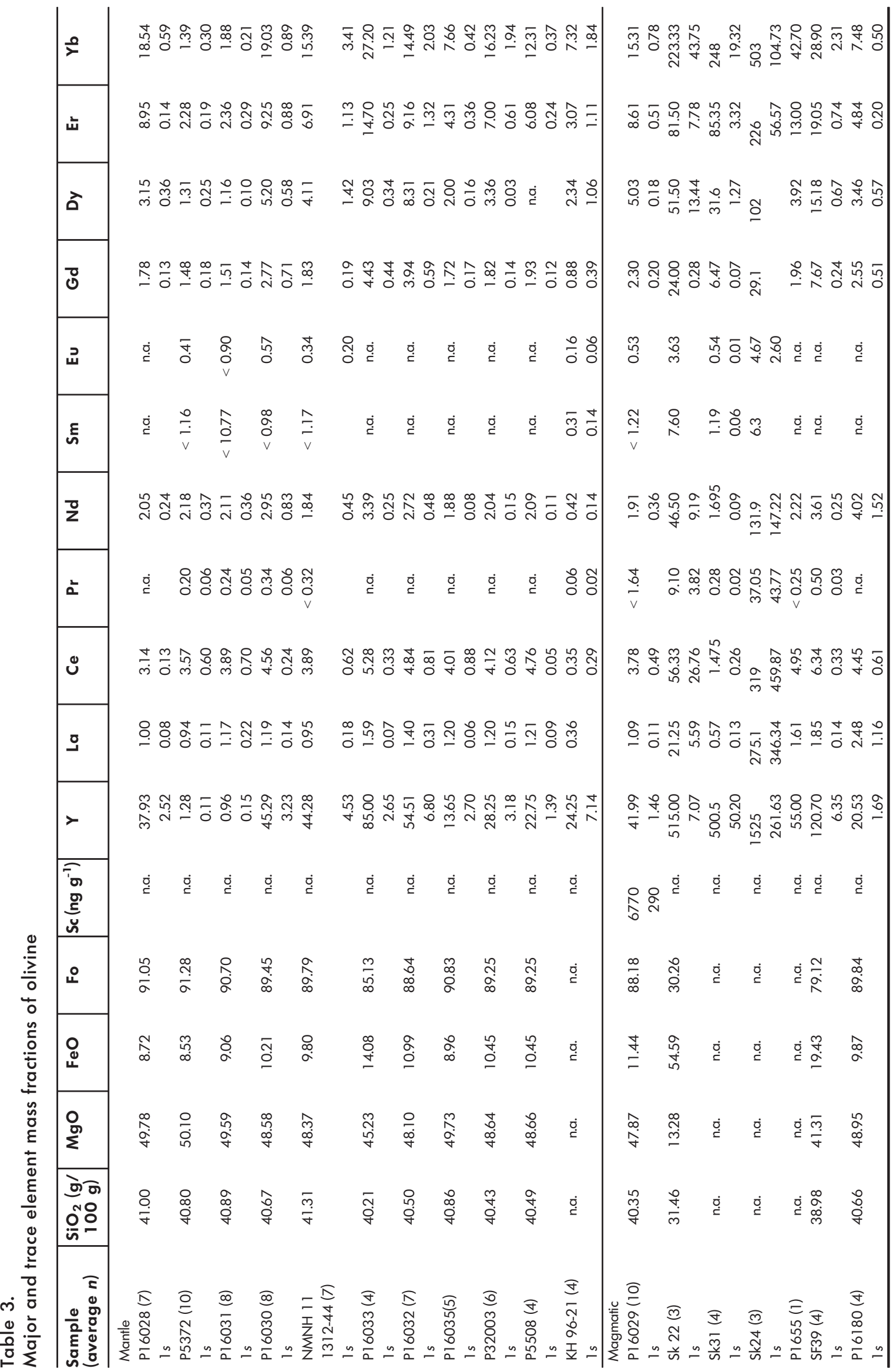




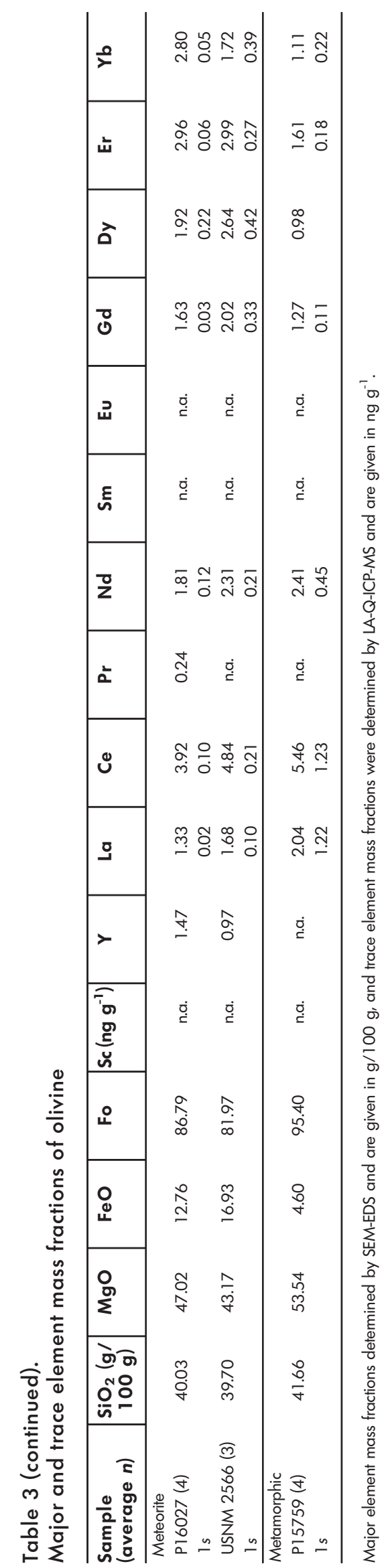

evidence that initially selected aliquots of olivine were mostly free of other mineral contaminants or metasomatic alteration features. Finally, since the aliquots were picked from several separate grains, it can also be concluded that the grains are chemically homogenous and of only one generation.

Scandium was one of the elements that showed excessive drift in five of the nine analysed aliquots, and only data for the remaining four are reported. The average Sc content of the two leached aliquots is somewhat lower $\left(6.4 \pm 0.4 \mu \mathrm{g} \mathrm{g}^{-1}\right)$ than for the unleached pair $\left(9.1 \pm 0.6 \mu \mathrm{g} \mathrm{g}^{-1}\right)$.

Yttrium and the HREEs (Dy to Lu) showed a very strong agreement between the leached and unleached aliquots and within aliquots, with the exception of one leached sample (CS51) that recorded higher mass fractions of all elements. The overall coherence between leached and unleached olivine shows that despite the very low mass fractions of these elements in olivine, secondary processes did not significantly alter the absolute and relative abundances of the HREEs. The MREES Sm to Eu were only quantifiable in a smaller subset of the leached and unleached samples and they show a wider range in concentrations. The LREEs La to Nd were not quantifiable in any sample due to the concentration of these elements in the procedural blank. The origin of the higher contents in leached sample CS51 is uncertain, but Rb was only detectable in this sample. If $\mathrm{Rb}$ is an appropriate proxy for alteration, this could indicate that the leaching step in this case did not successfully remove all traces of melt or altered olivine from cracks or grain boundaries. However, the Al content was the same as all other samples and it is noteworthy that the HREE pattern still parallels that of all other aliquots of $\mathrm{Pl} 6029$.

From the solution analyses, the mean REE values of both leached and unleached aliquots were compared with the laser ablation data from the same sample. Figure 4 a gives a comparison of $\mathrm{Cl}$-normalised REE patterns between the solution data sets for three olivine crystals (divided into nine aliquots) and the average laser ablation determined mass fractions for P16029 ( $n=10$ ), while Figure 4b gives a direct comparison between solution and laser ablation determined measured values for the same sample. Figure $4 \mathrm{a}$ shows that the laser data plot close to the average solution data for $\mathrm{Yb}, \mathrm{Er}$ and $\mathrm{Dy}$, and within error of the leached average for $\mathrm{Gd}$, resulting in comparable REE patterns for both data sets. There is also good agreement between absolute and relative HREE contents derived by solution and laser ablation, as shown in Figure 4b. Most elements plot consistently within error of the 10\% error 


\section{GEOSTANDARDS and
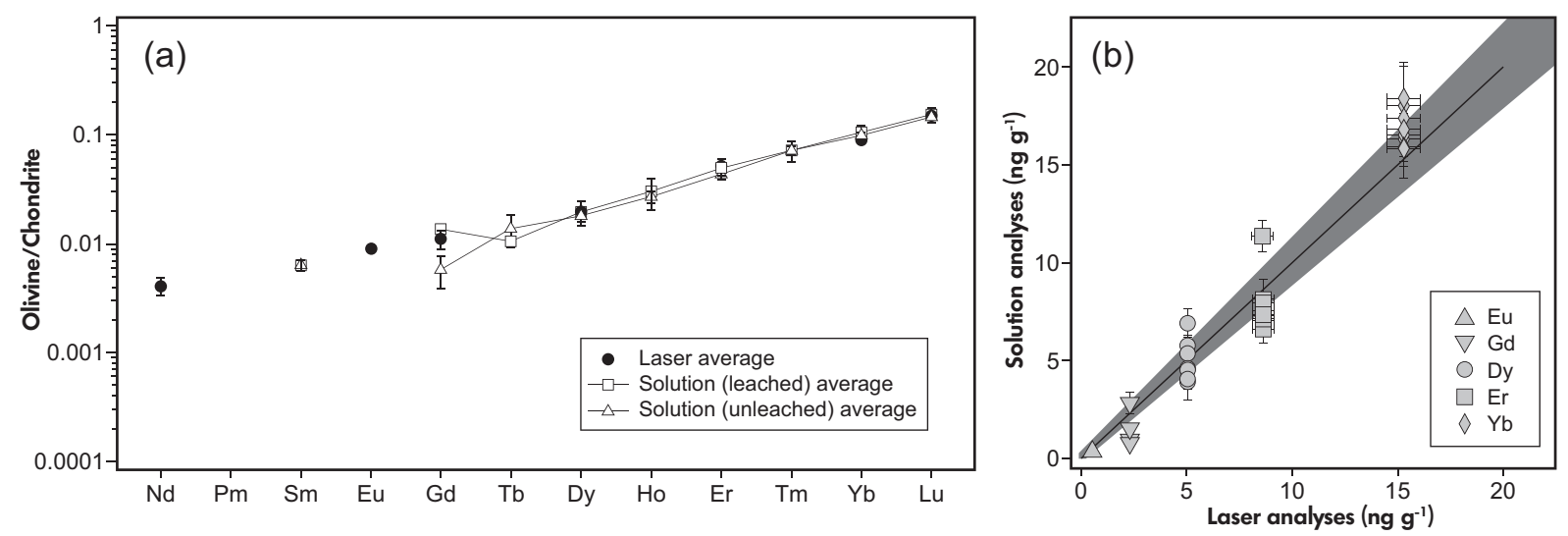

Figure 4. (a) Cl-normalised (values of McDonough and Sun 1995) partial REE patterns for average leached $(n=5)$ and unleached $(n=4)$ olivine groups (see Table S1) by S-Q-ICP-MS compared with the mean mass fraction determined for the same olivine by the LA-Q-ICP-MS $(n=10)$ method. Error bars represent one standard deviation of the mean of the final concentration. (b) Mean LA-ICP-MS mass fractions determined for Eu, Gd, Dy, Er and Yb compared with each determination (leached and unleached) of the same elements determined by S-Q-ICP-MS. Horizontal error bars represent one standard deviation of the mean of the final mass fractions (LA-Q-ICP-MS), whereas vertical error bars represent one standard deviation of the mean of the final intensity during measurement (S-Q-ICP-MS). A 1:1 line is given for ease of comparison, while the shaded area represents the $\pm 10 \%$ error envelope.

bracket of the 1:1 line, with the exception of Gd, which plots below the 1:1 line, perhaps from a slight inaccuracy in isobaric (e.g., Dy) interference correction. The overall concordance indicates that the data obtained using our ablation strategy is consistent with the more classically applied grain digestion and solution analysis.

\section{REE contents of natural olivine}

Mass fraction data for natural olivine grains are listed in Table 3 and range from 0.1 to double-digit $\mathrm{ng} \mathrm{g}^{-1}$, with HREE significantly more variable than LREE. Cl-chondritenormalised rare earth element patterns are illustrated in Figure 5. Notwithstanding this variation in the HREEs, all REE patterns are relatively similar with only a few exceptions observed in meteorite olivines. Four olivine samples (P5372, P16027, P16031 and USNM 2566; two mantle and two meteorite) exhibited lower than expected $\mathrm{Y}$ measured values. This is most evident from the Y/Ho ratio. Assuming a smooth $\mathrm{Cl}$-normalised REE pattern between $\mathrm{Dy}_{\mathrm{N}}$ and $\mathrm{Er}_{\mathrm{N}}$, the projected Ho $\mathrm{H}_{\mathrm{N}}$ position can be used to predict its mass fractions in the olivine, since this element was not measured by the LA-ICP-MS technique. From these extrapolated Ho data, Y/Ho mass ratios for LAICP-MS Y data returned a mean of $23 \pm 4.7$, with the exception of the four low $Y$ samples that yielded ratios from 1.2 to 2.4. Expressed another way, an assumed chondritic Y/Ho ratio of 28.8 (McDonough and Sun 1995) can be used to calculate a predicted $Y$ mass fraction for all samples. When the latter are compared with measured $Y$ values (as shown in Figure S2), most samples fall along the expected 1:1 line, with some increasing deviation at lower mass fractions expected from the lower precision. However, the four samples identified as anomalous plotted to clearly subchondritic $Y$ values. These low $Y$ values are apparently not an analytical artefact (Figure S3) and it is noted that unusually low $\mathrm{Y} / \mathrm{H}$ o ratios have previously been reported for mantle samples associated with metasomatism (e.g., Grégoire et al. 2000, Bodinier et al. 2004). As the $Y$ mass fractions for these four samples were the lowest measured in this study, an analytical artefact should not be completely dismissed, although it is difficult to envisage an analytical process that would lead to specific suppression of only the $\mathrm{Y}$ signal. For comparison, the directly measured mean Y/Ho ratio for P16029 (leached and unleached SQ-ICP-MS) was $27 \pm 2.9$, similar to the extrapolated laser data.

Mantle olivine: With a total abundance of ca. $\geq 60 \%$, olivine is the dominant mineral in upper mantle peridotite, the majority of it lying between $\mathrm{Fo}_{89}$ and $\mathrm{Fo}_{94}$ (Deer et al. 1997). These olivines have a very low affinity for REEs, with mass fractions estimated at low $\mathrm{ng}^{-1}$ levels.

The Cl-normalised REE patterns (Figure 5a) show that mantle-derived olivine ranged from low to high $\mathrm{La} / \mathrm{Yb}$ ratios. (0.002 to 1.8) The variability in La/Yb is mainly caused by relative HREE abundance. The LREEs are typically 


\section{RESEARCH}
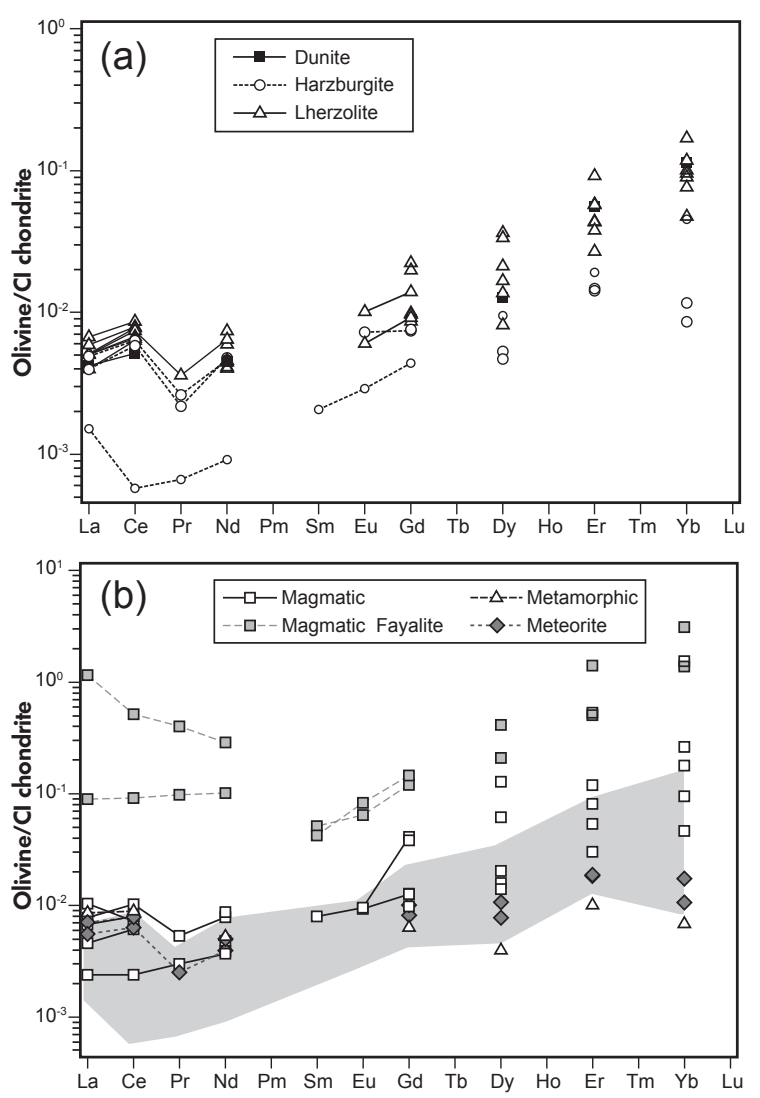

Figure 5. Cl-normalised (McDonough and Sun 1995) REE patterns in olivine, arranged by atomic mass. (a) Olivine/chondrite patterns for all mantle olivine samples in this study. (b) Olivine/chondrite patterns for magmatic, meteorite and metamorphic olivine samples for this study with a grey field representing the mantle samples.

100-1000 times lower than chondrite, while HREEs show greater variation from as little as ten times lower than chondrite. There is only limited petrological control over REE behaviour. Harzburgitic samples presented here display a wide range in La/Yb ratios, while the dunite and Iherzolites all show consistently higher ratios (Figure 5a) and similar patterns. Melt extraction to some degree is considered to be ubiquitous amongst peridotites (Walter 1981). This extraction process results in the depletion of REEs in olivine due to their incompatibility, preferentially removing the larger cations (LREEs), causing a positive slope in the REE pattern. The resulting low REE mass fractions in olivine mean that the mineral can in essence be described as a blank slate' upon which metasomatic enrichment patterns might be overprinted. This metasomatic enrichment generally adds LREE and so may result in the flattening out of a positive slope, or causing a slight U-shaped pattern.
Different metasomatic agents induce different REE patterns; for example, the normalised La/Yb ratios of clinopyroxenes are known to be much lower for those affected by silicate metasomatism than by carbonatitic metasomatism (Coltorti et al. 1999). It follows that the expected trends would show greater variation amongst the LREEs than the HREEs, as those elements are more strongly affected by metasomatism. The data presented here, however, show greater variation amongst the HREEs, with a trend for decreasing variability tapering across the mass range from the heavy to light REEs.

Magmatic olivine: Magmatic olivine grains exhibited the highest HREE mass fractions, clearly shown in Figure 5b. The LREEs were typically 100 times lower than chondrite, while HREEs were between 10 and 100 times lower. This variation in enrichment could be quantified by $\mathrm{La}_{\mathrm{N}} / \mathrm{Yb}_{\mathrm{N}}$ ratios, which ranged from 0.001 to 0.37 . Magmatic olivines overlap with those mantle olivines that have more elevated REE contents, but also extend to higher absolute REE mass fractions. Much of the variation seen amongst the magmatic olivines is due to the higher REE measured values of two samples from Skaergaard which contain higher fayalite contents, as can be seen in Figure 5b.

Meteorite olivine: Both meteorite-derived olivines analysed in this study displayed flatter REE patterns than the magmatic and mantle groups, with $\mathrm{La}_{\mathrm{N}} / \mathrm{Yb}_{\mathrm{N}}$ ratios of 0.32 and 0.66 , and mass fractions ca. 100 times lower than chondrite. These patterns are flatter than the v-shaped patterns typically reported for pallasite olivines in the literature, such as those abundances reported for the Brenham olivine by Masuda (1968). More recent work by Minowa and Ebihara (2002) on olivine from the same Brenham pallasite determined REE abundances after leaching, finding much flatter patterns than those previously reported by Masuda (1968) and others. The v-shaped patterns reported elsewhere for pallasite olivines are instead suggested to be the result of terrestrial contamination (Minowa and Ebihara 2002). The patterns presented here show a slight up-turn at the LREEs. Terrestrial alteration/contamination cannot be excluded as a reason for the LREEs upturn, although the in situ nature of our data certainly lowers this prospect compared with bulk digestion data.

\section{REE partitioning in olivine}

The olivine structure has two octahedral cation sites, MI and M2. The M1 site is smaller than M2, and it is generally assumed that the large cationic radii of REEs limit their 
partitioning into the larger M2 site (Evans et al. 2008). The optimum cationic radius $\left(r_{0}\right)$ in olivine $(0.81 \AA)$ is smaller than even the heaviest REEs, and the elastic modulus prevents significantly larger (i.e., LREEs) cations from successful substitution. There are several reports of apparent partition coefficients for REEs into olivine in the literature and these vary by more than two orders of magnitude not only in absolute but also relative behaviour of the REE (e.g., Stosch 1982, Eggins et al. 1998a, b, McDade et al. 2003, Lee et al. 2007, Evans et al. 2008, Sun and Liang 2013). It is suspected that a lot of this variation likely results from analytical difficulties including mass fractions approaching detection limits and uncorrected contamination from inclusions and grain boundaries (Lee et al. 2007). Recognising these limitations, attempts have been made to predict the partitioning behaviour of REEs in olivine with the lattice strain model and temperature correction equations (Witt-Eickschen and O'Neill 2005, Lee et al. 2007).

Here, we calculate apparent empirical REE partition coefficients for olivine using data from our in situ LA-Q-ICP-MS technique and present them within the context of theoretical models, experimental and other empirically determined values from the literature. For a few samples, it was possible to obtain apparent partition coefficients by dividing the olivine REE measured values with those in co-existing clinopyroxene and orthopyroxene, yielding $D_{\mathrm{ol} / \mathrm{cp} x}$ and $D_{\mathrm{ol} / \mathrm{opx}}$. For other (mineral separate) samples, where no suitable clinopyroxene or orthopyroxenes were available for analysis, REE mass fractions for the pyroxene phases were taken from the literature. This included peridotite olivines from San Carlos (NMNH $111312-44)$, Tallante (P32003) and Kilbourne Hole (KH 96-21) (Lee et al. 2007, Rampone et al. 2010,

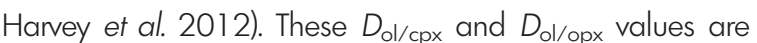
plotted in Figures $6 a, b$ against effective cationic radii (Onuma et al. 1968, Lee et al. 2007). For comparison, the figure also shows theoretical and experimental data from literature (Stosch 1982, Eggins et al. 1998b, McDade et al. 2003, Lee et al. 2007).

There is a strong negative correlation between $D_{\mathrm{ol} / \mathrm{cpx}}$ and $D_{\mathrm{o} / \mathrm{opx}}$ and cationic radius for HREEs and MREEs, with a close agreement between empirical, experimental (Eggins et al. 1998b, McDade et al. 2003) and theoretical values (Lee et al. 2007) providing additional confidence in the LAQ-ICP-MS method. The correlation between $D_{\mathrm{ol}} /$ mineral and cationic radius suggests that the REEs are structurally bound within the lattice rather than being present as microinclusions in olivine. The trends deviate towards the LREEs, where we see increasingly diverging variation from $\mathrm{Nd}$ to $\mathrm{La}$ in the literature data. This variation has been previously noted, for example by Stosch (1982) who suggested that the

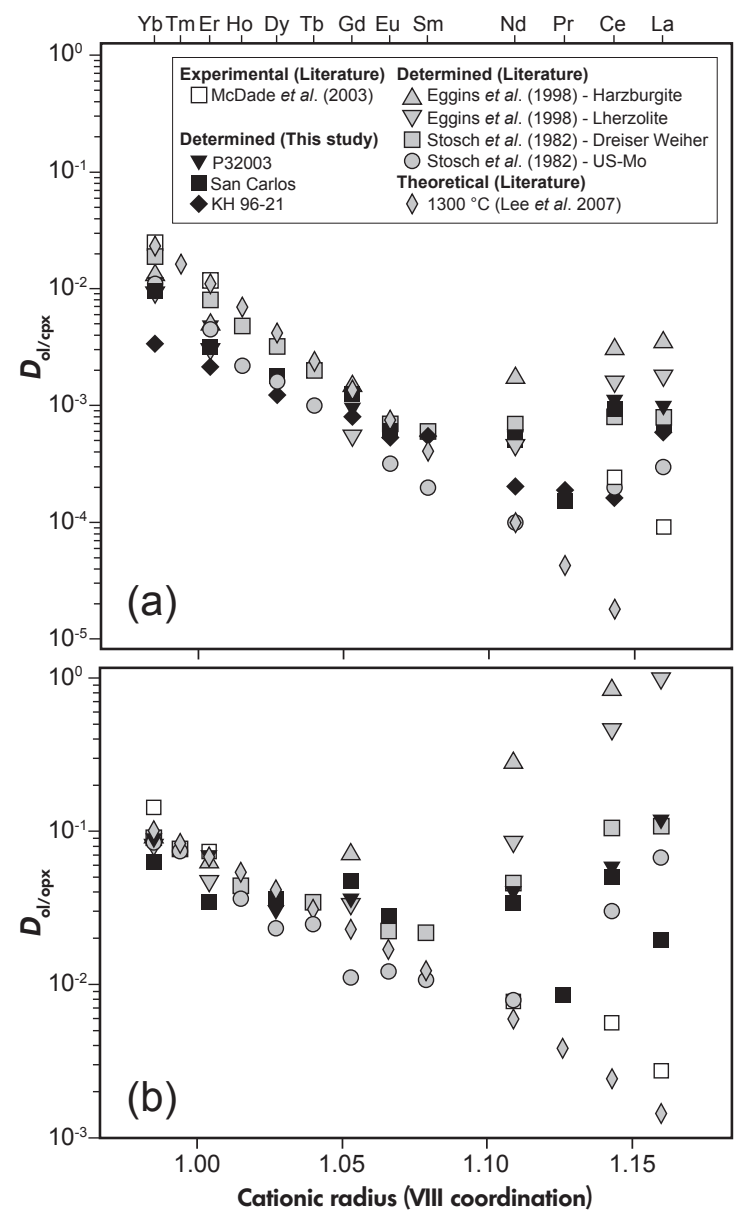

Figure 6. (a) $D_{\text {ol/cpx }}$ for empirically determined, experimental and theoretical data plotted against cationic radius. Samples shown from this study are San Carlos (NMNH $111312-44$ ) and a spinel lherzolite (P32003). Cationic radii are in eightfold co-ordination (Shannon 1976). (b) $D_{\text {ol/opx }}$ for empirically determined, experimental and theoretical data plotted against cationic radius. Samples shown from this study are San Carlos (NMNH $111312-44$ ) and a spinel lherzolite (P32003). Cationic radii are in eightfold co-ordination (Shannon 1976).

mass fraction of LREE in olivine might not be governed by lattice strain effects, and as such, LREE might not be structurally bound in the olivine lattice. Instead, the apparent mass fraction of these elements could be dominated by fluid inclusions or as surface contamination (Lee et al. 2007). While surface contamination should not be an issue using this laser ablation strategy, the effect of fluid inclusions cannot be excluded. Although common, this discrepancy at the LREE is not ubiquitous throughout the literature, with La contamination instead being attributed to analysis of small amounts of glass (McKay 1986, Beattie 1994, Evans et al. 2008). 


\section{Conclusions}

The LA-Q-ICP-MS technique described in this contribution successfully determined REEs ( $\mathrm{La}, \mathrm{Ce}, \mathrm{Pr}, \mathrm{Nd}, \mathrm{Sm}$, Eu, $\mathrm{Gd}, \mathrm{Dy}, \mathrm{Er}, \mathrm{Yb}$ ) and $\mathrm{Y}$ mass fractions in olivines from a global range, with observed absolute mass fractions from 0.1 to double-digit $\mathrm{ng} \mathrm{g}^{-1}$ levels. The REEs Sm to Lu and Y were determined in one in-house olivine (P16029) with a S-Q-ICP-MS technique for comparison and yielded results within 10\% of LA-Q-ICP-MS values. The LREEs were unquantifiable by S-Q-ICP-MS due to the high procedural blank for these elements. More detailed low-blank solution work, possibly including a preconcentration stage, is required to reinforce the authenticity of the observed LREE enrichment in the LA-Q-ICP-MS data. Calculation of $D_{\mathrm{ol} / \mathrm{cpx}}$ and $D_{\mathrm{ol} / \mathrm{opx}}$ suggests that the REEs are structurally bound in the olivine lattice, with HREEs and MREEs agreeing closely with experimental and theoretical values from the literature, suggesting a successful application of this LA-QICP-MS technique. While this method has been developed for the determination of REE in olivine, it may also be applied to other low abundance elements and to other minerals. Limited spatial resolution is a disadvantage with the technique; however, it may be used as a macrosampling method with the potential for widespread application.

\section{Acknowledgements}

We are grateful to Jason Harvey, lan Meighan and the Department of Mineral Sciences, Smithsonian Institution for donating samples for this study. Colin Reid is thanked for his help with the SEM-EDS analyses. We also thank the handling editor and the reviewers for their thoughtful and insightful comments. CVS is supported by the Trinity Postgraduate Award and the lveagh Fund. The LA-ICP-MS analytical facility at TCD was supported by grant (SFI/12/ ERC/E2499).

\section{References}

Babechuk M.G., Kamber B.S., Greig A., Canil D. and Kodolányi J. (2010)

The behaviour of tungsten during mantle melting revisited with implications for planetary differentiation time scales. Geochimica et Cosmochimica Acta, 74, 14481470

\section{Bau M. (1996)}

Controls on the fractionation of isovalent trace elements in magmatic and aqueous systems: Evidence from $\mathrm{Y} / \mathrm{Ho}, \mathrm{Zr} /$ $\mathrm{Hf}$, and lanthanide tetrad effect. Contributions to Mineralogy and Petrology, 123, 323-333.
Beattie P. (1994)

Systematics and energetics of trace-element partitioning between olivine and silicate melts: Implications for the nature of mineral/melt partitioning. Chemical Geology, $117,57-71$.

Bodinier J., Menzies M.A., Shimizu N., Frey F.A. and McPherson E. (2004)

Silicate, hydrous and carbonate metasomatism at Lherz, France: Contemporaneous derivatives of silicate meltharzburgite reaction. Journal of Petrology, 45, 299-320.

Bowen N.L. (1915)

The later stages of the evolution of igneous rocks. The Journal of Geology, 23, 1-91.

Coltorti M., Bonadiman C., Hinton R.W., Siena F. and Upton B.G.J. (1999)

Carbonatite metasomatism of the oceanic upper mantle: Evidence from clinopyroxenes and glasses in ultramafic xenoliths of Grande Comore, Indian Ocean. Journal of Petrology, 40, 133-165.

De Hoog J.C.M., Gall L. and Cornell D.H. (2010) Trace-element geochemistry of mantle olivine and application to mantle petrogenesis and geothermobarometry. Chemical Geology, 270, 196-215.

Deer W.A., Howie R.A. and Zussman J. (1997) Rock-Forming Minerals Volume 1A: Orthosilicates (2nd edition). Geological Society (London).

Eggins S.M., Kinsley L.P.J. and Shelley J.M.G. (1998a)

Deposition and element fractionation processes during atmospheric pressure laser sampling for analysis by ICPMS. Applied Surface Science, 127-129, 278-286.

Eggins S.M., Rudnick R.L. and McDonough W.F. (1998b) The composition of peridotites and their minerals: A laserablation ICP-MS study. Earth and Planetary Science Letters, $154,53-71$.

Eggins S.M., Woodhead J.D., Kinsley L.P.J., Mortimer G.E., Sylvester P., McCulloch M.T., Hergt J.M. and Handler M.R. (1997)

A simple method for the precise determination of $\geq 40$ trace elements in geological samples by ICP-MS using enriched isotope internal standardisation. Chemical Geology, 134, 31 1-326.

Evans T.M., O'Neill H.St.C. and Tuff J. (2008)

The influence of melt composition on the partitioning of REEs, Y, Sc, Zr and Al between forsterite and melt in the system CMAS. Geochimica et Cosmochimica Acta, 72, 5708-5721.

Foley S.F., Prelevic D., Rehfeldt T. and Jacob D.E. (2013)

Minor and trace elements in olivines as probes into early igneous and mantle melting processes. Earth and Planetary Science Letters, 363, 181-191.

Fryer B.J., Jackson S.E. and Longerich H.P. (1995) Design, operation and role of the laser-ablation microprobe coupled with an inductively coupled plasma-mass spectrometer (LAM-ICP-MS) in the Earth-sciences. Canadian Mineralogist, 33, 303-312. 


\section{GEOSTANDARDS and GEOANALYTICAL

references

Gibson S.A., McMahon S.C., Day J.A. and Dawson J.B. (2013)

Highly refractory lithospheric mantle beneath the Tanzanian craton: Evidence from Lashaine pre-metasomatic garnet-bearing peridotites. Journal of Petrology, 54, 1503-1546.

Grégoire M., Moine B.N., O'Reilly S.Y., Cottin J.Y. and Giret A. (2000)

Trace element residence and partitioning in mantle xenoliths metasomatized by highly alkaline, silicate- and carbonate-rich melts (Kerguelen Islands, Indian Ocean. Journal of Petrology, 41, 477-509.

Harvey J., Yoshikawa M., Hammond S.J. and Burton K.W. (2012)

Deciphering the trace element characteristics in Kilbourne Hole peridotite xenoliths: Melt-rock interaction and metasomatism beneath the Rio Grande Rift, SW USA Journal of Petrology, 53, 1709-1742.

Jarosewich E., Nelen J.A. and Norberg J. (1980)

Reference samples for electron microprobe analysis. Geostandards Newsletter, 4, 43-47.

Jochum K.P., Stoll B., Herwig K., Willbold M., Hofmann A.W., Amini M. and 47 others (2006)

MPI-DING reference glasses for in situ microanalysis: New reference values for element concentrations and isotope ratios. Geochemistry Geophysics Geosystems, 7, doi: 10 1029/2005GC001060.

Jochum K.P., Weis U., Stoll B., Kuzmin D., Yang Q., Raczek I., Jacob D.E., Stracke A., Birbaum K., Frick D.A., Günther D. and Enzweiler J. (2011)

Determination of reference values for NIST SRM 610 617 glasses following ISO guidelines. Geostandards and Geoanalytical Research, 35, 397-429.

\section{Kamber B. (2009)}

Geochemical fingerprinting: 40 years of analytical development and real world applications. Applied Geochemistry, 24, 1074-1086.

Krishnamurthy P., Gopalan K. and Macdougall J.D. (2000)

Olivine compositions in picritic basalts and the Deccan volcanic cycle. Journal of Petrology, 41, 1057-1069.

Lee C.-T.A., Harbert A. and Leeman W.P. (2007) Extension of lattice strain theory to mineral/mineral rare-earth element partitioning: An approach for assessing disequilibrium and developing internally consistent partition coefficients between olivine, orthopyroxene, clinopyroxene and basaltic melt. Geochimica et Cosmochimica Acta, 71, 481-496.

Masuda A. (1968)

Lanthanide concentrations in the olivine phase of the Brenham pallasite. Earth and Planetary Science Letters, 5, 59-62.

McDade P., Blundy J.D. and Wood B.J. (2003)

Trace element partitioning on the Tinaquillo solidus at 1.5 GPa. Physics of the Earth and Planetary Interiors, 139, 129-147.
McDonough W.F. and Sun S.S. (1995)

The composition of the Earth. Chemical Geology, 120, 223-253

McKay G.A. (1986)

Crystal/liquid partitioning of REE in basaltic systems:

Extreme fractionation of REE in olivine. Geochimica et

Cosmochimica Acta, 50, 69-79.

Minowa H. and Ebihara M. (2002)

Rare earth elements in pallasite olivines (abstract). Lunar and Planetary Science XXXIII, abstract \# 1386. Lunar and Planetary Institute, Houston.

Murck B.W., Burruss R.C. and Hollister L.S. (1978)

Phase equilibria in fluid inclusions in ultramafic xenoliths. American Mineralogist, 63, 40-46.

Nagasawa H. (1966)

Trace element partition coefficient in ionic crystals. Science, $152,767-769$

Onuma N., Higuchi H., Wakita H. and Nagasawa H. (1968)

Trace element partition between two pyroxenes and the host lava. Earth and Planetary Science Letters, 5, 47-51.

Paton C., Hellstrom J., Paul B., Woodhead J. and Hergt J. (2011)

lolite: Freeware for the visualisation and processing of mass spectrometric data. Journal of Analytical Atomic Spectrometry, 26, 2508-2518.

\section{Roedder E. (1965)}

Liquid $\mathrm{CO}_{2}$ inclusions in olivine-bearing nodules and phenocrysts from basalts. American Mineralogist, 50, 1746-1782.

Qi L., Zhou M.F., Malpas J. and Sun M. (2005) Determination of rare earth elements and $Y$ in ultramafic rocks by ICP-MS after preconcentration using $\mathrm{Fe}(\mathrm{OH})_{3}$ and $\mathrm{Mg}(\mathrm{OH})_{2}$ coprecipitation. Geostandards and Geoanalytical Research, 29, 131-141.

Rampone E., Vissers R.L.M., Poggio M., Scambelluri M. and Zanetti A. (2010)

Melt migration and intrusion during exhumation of the Alboran lithosphere: The tallane mantle xenolith record (Betic Cordillera, SE Spain). Journal of Petrology, 51, 295-325.

Shannon R.D. (1976)

Revised effective ionic radii and systematic studies of interatomic distances in halides and chalcogenides. Acta Crystallographica, 32, 751-767.

Sobolev N.V., Logvinova A.M.r Zedgenizov D.A. and Pokhilenko N.P. (2008)

Olivine inclusions in Siberian diamonds: High-precision approach to minor elements. European Journal of Mineralogy, 20, 305-315. 
references

Spandler C. and O'Neill H.St.C. (2009)

Diffusion and partition coefficients of minor and trace elements in San Carlos olivine at $1300{ }^{\circ} \mathrm{C}$ with some geochemical implications. Contributions to Mineralogy and Petrology, 159, 791-818.

Stosch H.-G. (1982)

Rare earth element partitioning between minerals from anhydrous spinel peridotite xenoliths. Geochimica et Cosmochimica Acta, 46, 793-811.

\section{Sun C. and Liang Y. (2013)}

The importance of crystal chemistry on REE partitioning between mantle minerals (garnet, clinopyroxene, orthopyroxene and olivine) and basaltic melts. Chemical Geology, $358,23-36$.

Ulrich T., Kamber B.S., Woodhead J.D. and Spencer L.A. (2010)

Long-term observations of isotope ratio accuracy and reproducibility using quadrupole ICP-MS. Geostandards and Geoanalytical Research, 34, 161-174.

Van Orman J.A., Grove T.L. and Shimizu N. (2001) Rare earth element diffusion in diopside: Influence of temperature, pressure and ionic radius, and an elastic model for diffusion in silicates. Contributions to Mineralogy and Petrology, 141, 687-703.

Walter M.J. (1981)

Melt extraction and compositional variability in mantle lithosphere. Treatise on Geochemistry, 2, 363-394.

Witt-Eickschen G. and O'Neill H.St.C. (2005)

The effect of temperature on the equilibrium distribution of trace elements between clinopyroxene, orthopyroxene, olivine and spinel in upper mantle peridotite. Chemical Geology, 221, 65-101.

Zanetti A., Tiepolo M., Oberti R. and Vannucci R. (2004) Trace-element partitioning in olivine: Modelling of a complete data set from a synthetic hydrous basanite melt. Lithos, 75, 39-54.
Zhang Z., Mao J., Cai J., Kusky T., Zhou G., Yan S. and Zhao L. (2008)

Geochemistry of picrites and associated lavas of a Devonian island arc in the northern Junggar terrane, Xinjiang (NW China): Implications for petrogenesis, arc mantle sources and tectonic setting. Lithos, 105, 379-395.

\section{Supporting information}

The following information may be found in the online version of this article:

Figure S1. Cl-chondrite normalised REE patterns for all S-Q-ICP-MS measurements P16029 olivine grains.

Figure S2. Plot of measured against theoretically predicted $Y$.

Figure S3. Raw counts vs. time for $\mathrm{Si}, \mathrm{Y}$ and $\mathrm{Yb}$ for $\mathrm{a}$ typical measurement run.

Table S1. Major and trace element mass fractions for olivine by solution quadrupole ICP-MS

Table S2. Trace element mass fractions of reference materials determined by LA-Q-ICP-MS.

Table S3. Background equivalent concentrations (BEC).

Table S4. Trace element background rates.

This material is available as part of the online article from: http://onlinelibrary.wiley.com/doi/10.1111/ggr.121 57/abstract (This link will take you to the article abstract). 